\title{
Indonesian EFL Teachers' Perspective on Intercultural Communicative Competence
}

\author{
Khoirunisa \\ Universitas Pendidikan Indonesia \\ khoirunisa237@upi.edu
}

\begin{abstract}
Teaching and learning English as a second/foreign language in this globalization era should be taught along with teaching culture. Culture underlies all language learners' emotion, cognition, and their senses of who they are. The purpose of this study to analyze teachers' views on intercultural communicative competence in language teaching and learning process and to analyze the benefits of having cultural information included in Foreign Language teaching on teachers' perspectives. The method used in this research is descriptive qualitative design. The study used the interview as data collection techniques to gain a rich description of the teachers' perspective towards Intercultural Communicative Competence. The participants of this study were one Indonesian English teacher in Bandung, West Java and two English teachers from Banten who taught English as a foreign language for students at the secondary level which is Junior High School level. The analysis shows that the teachers consider teaching culture an important factor as included in the language. The majority of the participants underlined the importance of knowing habits, values, social ethics, and the identity of people from a different culture. The study suggests that the teachers share cultural knowledge with students through intercultural competence in their teaching process beyond the textbook.
\end{abstract}

Keywords: intercultural communicative competence, EFL teachers, language, culture

\section{INTRODUCTION}

Two languages and culture were involved when someone learned second/foreign language, the first is their original culture and the target language culture. Zhou and Griffiths (2011) stated when someone learns a language they also learn about the target language culture to improve learners' comprehension of the cultural concept and the relationship with the language Learners need not just knowledge and skill in the grammar of a language but also the ability to use the language in socially and culturally appropriate ways. Brown and Heekyeong (2015) suggested when learning and teaching an additional language, both teachers and learners must be aware of the complex and dynamic relationship between language and cultural customs, values, and beliefs that are embedded in language practice. Building cultural awareness encourages learners to have an interest in knowledge, and an opening towards foreign cultures, peoples and countries.

The communicative language teaching should be viewed towards an intercultural perspective become a crucial element in the teaching and learning process. According to Huang, Rayner, and Zhuang (2003), a person who has intercultural competence can develop relationships with people from different cultures and manage to solve complicated conflicts by crossing the barriers that arise. There are many researchers conducted a study related to this topic. Zhou and Griffiths (2011) observes the failures in students' intercultural communication and explores the intercultural knowledge needs to be delivered to students in the classroom at a university in Beijing, China. The research conducted by Abdulrahman, Usu, and Tanipu (2016) investigate teachers opinion and their attitudes towards the integration of culture and English language education. Teachers should be aware of intercultural competence so they can deliver the cultural knowledge, attitudes and also skill to the language learners in their classroom. For these reasons, this research is conducted to promote Intercultural Communicative Competence (ICC) for English teachers to develop their cultural sensitivity and to encourage them to teach intercultural communicative competence in their classroom to make the learners competent to use the target language for effective communication.

\section{A. Defining Language and Culture}

Karabinar and Guler (2012) define language as one of the criteria of the social system in a community. Liddicoat and Scarino (2013) explain the roles of language as three parts, namely language as a structural system, language as a communicative system, and language as a social practice. It can be said that language is not only a set of the structure of words, but it is also used appropriately as communication in communities that includes socio-cultural aspects, that the language can be accepted and understood by people (Miftakh, 2017).

Culture is a challenging concept to define and it is cannot separate from the concepts of ethnicity and nationality. Clayton, Herbert, and Middleton (2003) defines culture as the root of our identity which pervasive, shared, learned and dynamic. According to Brown and Heekyeong (2015) culture is a way of life. It is the context within which we exist, think, feel, and relate to others. Culture is a system and a context that rules a group of people to think, feel, behave and connect one to another. Culture is shared and learned by people in the same group and can be transferred and adapted by another group of people.

\section{B. The Relationship between Language and Culture}

When learners learn about the language they learn about the culture and as they learn to use a new language they learn to communicate with other individuals from a new culture 
(Byram, 1989). Similar to Byram's opinion, Zhou \& Griffiths (2011) stated when someone learns a language they also learn about the target language culture to improve learners' comprehension of the cultural concept and the relationship with the language. As a result of this relationship, culture teaching has gained importance in foreign language teaching, especially in the field of English language teaching. Thus, culture teaching should be paid special attention to the EFL curriculum together with the necessary methods and techniques to be applied in the classroom.

In the modern second/foreign language classroom the target cultures play an essential role in language learning. Teaching culture has been commonly known in English language teaching. Marek (2008) pointed out in his research that the target language culture is an essential component in the process of effective language learning and teachers are strongly recommended to cover more of the target language culture in the classroom. Students' respect for cultural differences can be greatly improved in the process of language learning in the classroom if the teachers incorporate culture into the language teaching process. However, students' knowledge about the target cultures often seems very limited. In learning English at school and university, there is not necessarily a guarantee to implement an intercultural approach that the cultural aspects of the target language are also studied, or at least inserted in each lesson including in the materials (Miftakh, 2015). Moloney (2007) stated language, culture, and learning are understood as fundamentally interrelated. Both the form of the language and the messages conveyed in it are understood to provide cultural knowledge.

\section{Intercultural Communicative Competence}

Bennett (2015) describes intercultural competence is increasingly defined in greater complexity, which often acknowledges the vital role of identity, the nature of intercultural development, and the interconnectedness of intercultural competence within wider contextual situations. Intercultural competence, which is the ability to change someone's knowledge, attitudes, and behaviors to be open and flexible to other cultures, has become a key issue in the globalized society of the $21^{\text {st }}$ century (Alred \& Byram, 2002). Byram's definition of intercultural competence derived the knowledge, skills, and attitudes, which a foreign language teacher should possess to be able to teach intercultural competence. Intercultural competence is often considered to be a subfield of "communicative competence" (Deardorff, 2009). Matveev (2017) stated that intercultural competence differs from intercultural communication competence since the former views the skills necessary to be culturally competent whereas the latter mainly focuses on a person's communication skills in intercultural encounters.

The goal of intercultural language teaching is to improve learners' intercultural communicative competence, as well as their awareness of intercultural communication. Feng, Byram, \& Fleming (2009) define intercultural experience takes place when people from different social groups with different cultures (values, beliefs, and behaviors) meet. Byram's (1997) model of Intercultural Communicative Competence (ICC), is one of the most famous Intercultural Competence models, which is in turn divided into five components namely savoirêtre, savoirs, savoir-comprendre, savoir-apprendre, and savoirengager. Sercu (2005) mentions in the context of foreign language education, intercultural competence is linked to communicative competence in a foreign language. Additional knowledge, attitudes, competencies, and skills are needed for the teachers who teach intercultural communicative competence to support their teaching practice. The teacher should have a broad knowledge of their own culture so they can explain to the student the similarities or the differences between their own culture and the target language culture.

Zhang (2017) requires second/foreign language teachers to prepare themselves in three aspects, first, they should have sufficient intercultural knowledge. Second, teachers can communicate with others in English inside and outside the classroom, other intercultural occasions in particular. Third, ESL teachers have the following emotional qualities.

In Indonesian Education policy, the government tends to consider that foreign languages will diminish the people's sense of nationality (Sukarno, 2012). It seems that the government assumes that the foreign culture in the English language teaching possibly can give bad effects on the Indonesian culture. For the language teacher, it is important to filter the cultural knowledge that will be delivered, determine what is taught, what is the methods and strategies the teacher can be used in teaching culture in EFL classes.

\section{METHOD}

\section{A. Research Design}

The method used in this research is descriptive qualitative design. According to Hamied (2017), a distinctive feature of qualitative research is that it allows researchers to identify issues from the perspective of participants and understand the meanings and interpretations that they give to behavior, events or object. The initial data from the interview then become the base for conducting data as the instrument to gain a more in-depth understanding of EFL teachers' perspectives on intercultural communicative competence and the implementation in their teaching practice.

To analyze teachers' view on Intercultural Communicative Competence in language teaching and learning process and to analyze the benefits of having cultural information included in Foreign Language teaching on teachers' perspective the research question was formulated "what are English teachers' perspectives on Intercultural Communicative Competence in language teaching and learning?"

\section{B. Data Collection}

Before collecting the data, the researcher asks approval to the teachers. Then, the researcher elaborates on the research overview and ask whether they are familiar with the terms intercultural competence and discuss the technique of interview. The interview finally was done through Whatsapp, since it was deemed to be more well-organized and efficient. The study used the interview as data collection techniques to gain a rich description of the teachers' perspective towards intercultural communicative competence. 


\section{Research Participants}

The participants in this study were three Indonesian English teachers. One teacher is from Bandung, West Java, and two teachers are from Banten who teach English as a foreign language for students at the secondary level which is Junior High School students.

\section{Instrument of Research}

The researcher will give the participants a semi-structured question adapted from Zhou and Griffits (2011) and Karabinar and Guler (2012). The audio record the conversation regarding the interview session.

\section{FINDINGS AND DISCUSSION}

To get qualitative data, an interview with the semistructured format, consisting of 8 open-ended questions was conducted with each participant about the concept of culture, the importance of culture in EFL, the preferred topics and issues, how they promote intercultural competence in their classes was distributed to three EFL teachers in Bandung and Banten. Biographic details including their name, ages, gender, school/class, and teaching experience were asked for teachers' identity. When asked the first 1 question "How would you define culture?" All the participant answered:

Culture is an identity. It is also a belief that people hold. Culture is also a habit.

Culture is characteristic and habitual of a particular group of people encompassing language, religion, and social habits.

Culture is great every country has its culture and culture is a habitual activity that people always do in life.

In defining culture, most teachers referred to it as a habit, identity, belief such as religion and language in a particular group of people. In line with Bennett's (2015) research that describes intercultural competence as the vital role of identity, the nature of intercultural development, and the interconnectedness of intercultural competence within wider contextual situations.

When the participants asked "What is the connection between language and culture?" they answered:

Language is a part of a culture, so they cannot be separated. The way we speak a particular language and the way we communicate using that language to convey messages can be influenced by culture.

Language is important as a tool of communication to understand the culture especially for the people who want to learn about the culture.

Language as a part of culture is a system of communication that people must speak a language. Language and culture is related to one another it can't be separated because it working together.

The participant emphasized that language and culture is an important thing as a part of communication and cannot be separated. When you learn about new language it includes cultural element as a part of the communication system and the learner should accept and tolerate the cultural diversity in a new community.

When the EFL teachers asked "In your mind, what are the outstanding benefits of having cultural information included in Foreign Language teaching?" the participant answer:

I think we can teach which words that can or cannot be spoken to a particular person in a particular situation when engaging in communication because some words may or may not be accepted in certain culture. We can teach, let's say English Jokes, existing in the culture. We can also teach expressions performed by native speakers of a foreign language when they use their language.

First, we can understand the other people in a different culture, so it can be self-destructive when communicating with other people so that it can create lasting relationships or communication, besides that we can also be more sensitive to things they don't like.

The outstanding benefit of cultural teaching is to know about a foreign culture is needed teacher can share their knowledge to the student not only what teachers know but they should know everything to share with the student beyond the textbook. Cultural awareness is needed we have to dig more information.

Most of the teachers understand that learning language should along with culture to help learners communicate inappropriate ways, to avoid the taboo and to understand other people from a different culture. those statements similar to Huang, Rayner, and Zhuang (2003) state that a person who has intercultural competence can develop relationships with people from different cultures and manage to solve complicated conflicts by crossing the barriers that arise.

The question "Why do you think it is important to teach about culture?" were asked to gain their views about how much important intercultural competence in teaching practice and the answer were

It is important because I want my students to respect their own and other's identity when they communicate.

Teaching foreign cultures is very important to students so that they have the provision of communication when dealing with foreigners who have cultural differences. They will develop abilities in order to think critically and to solve cultural problems. Moreover, student will enrich their point of view about the other culture and they will be able to see their own culture from different perspectives.

This is really important because in the future or next day our students or ourselves we met foreigner that we don't know about their culture and we made some mistakes when communicating with people.

The answers mention that teaching foreign culture is important for the student to respect cultural differences between people in a community. Culture is open to the elements that are diverse and contradictory, and different interpretations may be made of the same events by individuals 
who may be considered to be from the same culture (Miftakh, 2017).

When the EFL teachers asked "How important do you think to know about the foreign culture when communicating with the people of that culture?" the answers were:

Well, I have no idea. I think when we talk to others having different cultures, we have to try to adjust it. Probably it's for the sake of respecting their culture. However, we should also consider our own culture. Don't let it shift just because we want to communicate with foreigners.

It's very important to know the other culture when we communicate because Culture is the strongest part of people's lives, it influences their habitual, their humor and their worries. So when we communicate with people and try to build relations with them, it helps us to have some perspective and understand other cultures.

From the interview above two participant answers that teaching culture is very important, and one teacher suggest that even though teachers deliver culture along with teaching language we cannot forget our own culture and do not let is shift our identity. The language teacher should filter the cultural knowledge they will be delivered, determine what is taught, what is the methods and strategies the teacher can be used in teaching culture in EFL classes.

The question "What should students learn about target language culture to improve their intercultural communicative competence?" asked to know what aspect of culture should be taught to the student, and the answer by knowing their habits.

\section{Of course by having conversations with other people from} different cultures and know their habits.

They should learn the habitual and the attitude of a different culture.

An addition to what should students learn about target language culture besides the habits, teachers can give materials to students such as personal attributes such as display of respect, interaction posture, orientation to knowledge, empathy, interaction management, tolerance of ambiguity, etc (Cetinavci, 2012).

When the EFL teachers asked, "How do Indonesian students effectively improve their intercultural communicative competence?" Their opinion as follows:

Habits, social ethnic, education, and perhaps religion

I think they can effectively improve their IC.

Indonesian students can improve their communicative intercultural effectively if they live in its culture, or they trying to know and understand where the situations when communicate with foreigner. They can effectively improve their intercultural communicative competence with watching movie, join English club, learn from the foreigner or read a book about the target language culture.

From the interview, one teacher answered that by learning their habits, social ethnic, education, and religion and the other teacher answer that the way to improve student ICC by effectively improve their intercultural communicative competence watching the movie, join English club, learn from the foreigner or read a book about the target language culture. That can be a strategy to introduce the cultural element to the learners.

When the EFL teachers asked "What do you think English teachers should do in class to help the students improve their intercultural communication skills?" they suggest some methods that teachers can do in their teaching practice

English teachers can show students 'western movies', divide students into groups and have them play a role in which $1^{\text {st }}$ group impersonates people, let's say, from England, $2^{\text {nd }}$ group imitates people from Korea, $3^{\text {rd }}$ group pretend to be people from France, etc.

The teacher can ask the student a question to a native speaker or role-play situation where they develop their intercultural competence. If the teacher can use the internet to have students communicate orally with native speakers.

Each school has its way to make the students be able to speak actively. But in our school, we use the Macmillan textbook, a book that carries the British style. Students love of drawing and watching and also listening. As an English teacher, we have to know the students' skills, whether audio? Visual? Or kinesthetic? After we knew their type of learning, we choose the best way for them. If necessary, we can combine the three in the same way as the learning period. And it's a big deal. We bring a native to the school to measure their speaking even their improvement of the speaking. Maybe once in a month or twice a year.

Abdulrahman et. al (2016) found out the teachers can include cultural content that concerns factual culture as food, music people and housing in classroom teaching and teacherassigned projects for the student to explore foreign food, music, and tradition. The teacher also can use a variety of teaching activities such as role-play, brainstorming, discussion, and cross-cultural scenarios based on the objectives of the lesson.

According to the result of the teachers' answer from a question in the interview, most of the teacher consider teaching culture is an important thing because language is part of the culture and cannot be separated, the majority of the participants underlined the importance of shared norms, habit, values, social ethic, behavior, and identity. Most of the teachers stated that there is a mutual relationship between language and culture and they pointed out that culture provides a context for communication. As a result of this relationship, culture teaching has gained importance in foreign language teaching (FLT), especially in the field of English language teaching (ELT), culture teaching should be paid special attention in EFL curriculum together with the necessary methods and techniques to be applied in the classroom (Cetinavci, 2012). Teachers believed that culture teaching is important so that learners can learn and understand the English language appropriately in their cultural context. The teachers understand that learning language should along with culture to help learners communicate in appropriate ways, to avoid taboo and to understand other people from a different culture. One 
teacher suggests even though teachers deliver culture along with teaching language teachers cannot forget our own culture and do not let is shift our identity. The teacher needs to filter the positive side of a culture that can be transferred to the student to improve their ability to speak with people from a different culture. One of the objectives of the intercultural communicative competence is to bring up learners as citizens of the global society. When EFL learners develop their intercultural competence, they get to acquire the necessary skills to communicate effectively and live harmoniously with the members of such a society. Every teacher has different ways to deliver their knowledge of intercultural competence to the student. Most of the teachers suggest role play as a technique to deliver intercultural competence, the other teacher suggest watching the western movie, learning from British textbook, and even invite the native speaker to their school to improve students speaking skill one in a month or twice a year.

\section{CONCLUSION}

This study analyzes teachers' view on Intercultural Communicative Competence in language teaching and learning process and to analyze the benefits of having cultural information included in Foreign Language teaching on teachers perspective. The findings revealed that the teachers acknowledged the importance of intercultural competence in the EFL classroom, the teachers' perceptions of Intercultural Communicative Competence can be a key means for raising cultural teaching practices in the classroom. The findings of the study will be of interest to anyone desiring to find out how foreign language teachers view intercultural competence and how their views impact their teaching. The teacher should know everything to share with the student about intercultural competence in knowledge, skill, or attitudes aspect beyond the textbook

\section{REFERENCES}

Abdulrahman, T., Usu, N. R., \& Tanipu, Z. (2016). Teachers' Perspectives on the Integration of Culture and EFL. Journal of ELT Research,. 1(2), 180-193. doi: 10.22236/JER_Vol1Issue2

Alred, G., \& Byram, M. (2002). Becoming an intercultural mediator: A longitudinal study of residence abroad. Journal of Multilingual and Multicultural Development, 23(5), 339-352. doi: $10.1080 / 01434630208666473$

Bennet, J . M. (2015). The SAGE encyclopedia of intercultural competence. USA: SAGE Publications.

Brown, H. D., \& Heekyeong, L. (2015). Teaching by principles: An interactive approach to language pedagogy. USA: Pearson Education Inc.
Byram, M. (1989). Cultural studies in foreign language education. Bristol: Multilingual Matters.

Byram, M. (1997). Teaching and assessing intercultural communicative competence. Bristol: Multilingual matters.

Cetinavci, U. R. (2012). Intercultural communicative competence in ELT. Procedia - Social and Behavioral Sciences, 46, 3445-3449. doi: 10.1016/j.sbspro.2012.06.082

Clayton, M., Herbert, T., \& Middleton, R. (2003). The cultural study of music: A critical introduction. Abingdon, United Kingdom: Routledge.

Deardorff, D. K. (2009). The SAGE handbook of intercultural competence. USA: SAGE Publications Inc.

Feng, A., Byram, M., \& Fleming, M. (2009). Becoming interculturally competent through education and training. Bristol: Multilingual Matters.

Hamied, F. A. (2017). Research methods: A guide for first-time researchers. Bandung: UPI Press.

Huang, Y., Rayner, C., \& Zhuang, L. (2003). Does intercultural competence matter in intercultural business relationship development? International Journal of Logistics Research and Applications, 6(4), 277-288. doi: 10.1080/13675560310001626963

Karabinar, S., \& Guler, C. Y. (2012). A review of intercultural competence from language teachers' perspective. Procedia - Social and Behavioral Sciences, $70, \quad 1316-1328 . \quad$ doi: 10.1016/j.sbspro.2013.01.193

Liddicoat, A. J., \& Scarino, A. (2013). A.Intercultural language teaching and learning. West Sussex: Wiley-Blackwell.

Marek, D. (2008) The Place of the Target Language Culture in the Language Classroom: A Few Modest Proposals. In M. Pawlak (Ed.), Investigating English Language Learning and Teaching (pp. 347356). Poznań: Adam Mickiewicz University

Matveev, A. (2017). Intercultural competencenin organizations a guide for leaders, educators, and team players. Switzerland: Springer, Cham.

Miftakh, F. (2015). Investigating Indonesian EFL students' responses of the implementation of intercultural language learning. Journal of English Education, 4(1), 66-74.

Miftakh, F. (2017). Intercultural English teaching and learning to young learners. Paper presented at the Fifth International Seminar on English Language and Teaching (pp. 347-356).

Moloney, R. A. (2007). Intercultural competence in young language learners: A case study (Unpublished doctoral thesis). University of Sydney.

Sercu, L. (2005). Foreign Language Teachers and Intercultural Competence. Multilingual Matters Ltd.

Sukarno. (2012). Integrating local cultures in teaching English as a foreign language for character building. Jurnal Pendidikan Karakter, 2(2), 202-212. doi: 10.21831/jpk.v0i2.1304

Zhang, Y. (2017). A study on ESL teachers' intercultural communication competence. English Language Teaching; 10(11). doi: 10.5539/elt.v10n11p229

Zhou, C., \& Griffiths, C. (2011). Intercultural communicative competence. Canadian Center of Science and Education, 1(2), 113-122. doi: 10.5539/ells.v1n2p113 